\title{
The Wiskott-Aldrich Syndrome
}

\author{
RESULTS OF TRANSFER FACTOR THERAPY
}

\author{
Lynn E. Spitler, Alan S. Levin, Daniel P. Stites, H. Hugh Fudenberg, \\ Bernard Pirofsky, Charles S. August, E. Richard Stiehm, \\ Walter H. Hitzig, and Richard A. Gatti
}

From the Section of Immunology and Hematology, Department of Medicine, and the Department of Pediatrics, School of Medicine, University of California, San Francisco, California 94122; the Department of Pediatrics, Kaiser-Permanente Medical Group, San Francisco, California 94122; the Division of Immunology and Allergy, University of Oregon Medical Center, Portland, Oregon 97201; the Department of Pediatrics, University of Colorado, Denver, Colorado 80220; the Department of Pediatrics, University of California at Los Angeles, Los Angeles, California 90024; the Department of Pediatrics, Kinderspital Zurich, Universitat Kinderklinik, Zurich, Switzerland; and the Department of Pediatrics, University of Minnesota, Minneapolis, Minnesota 55455

A в S TRACT 12 patients with Wiskott-Aldrich syndrome were treated with therapeutic doses of transfer factor in an attempt to induce cellular immunity. Clinical improvement was noted after transfer factor therapy in 7 of the 12 patients treated. Because this disease has a variable course and temporary spontaneous improvement can occur, the observed improvement cannot necessarily be attributed to the transfer factor. However, in two patients repeated remissions consistently followed transfer factor administration on repeated occasions. This included freedom from infections, regression of splenomegaly, and clearing of eczema. An unexpected finding was a decrease in bleeding in 3 of the 10 patients who had bleeding. Conversion of skin reactivity was obtained in all seven patients who clinically seemed to respond to

Presented in part at the national meeting of the American Society of Clinical Investigation, Atlantic City, N. J., May 1971; the Sixth Annual Leukocyte Culture Conference, Rosario, East Sound, Wash., June 1971 ; and the First International Congress of Immunology, Washington, D. C., August 1971.

Dr. Spitler was the recipient of a Durnham Fellowship (D-161) and now holds a Research Career Development Award (I-K4-A1-43012). Dr. Levin was a trainee under U. S. Public Health Service Training Grant (HE-05677) and now holds a Faculty Research Award from the American Cancer Society (FRA-12519). Dr. Stites is a trainee under U. S. Public Health Service Training Grant (HE05677). Dr. Gatti is the recipient of a Research Career Development Award (5-K4-A143078-02).

Received for publication 8 April 1972 and in revised form 2 August 1972. transfer factor. In vitro studies performed after the administration of transfer factor demonstrated that the lymphocytes of the patients now produced migration inhibitory factor in response to appropriate test antigens, but did not undergo increased radioactive thymidine incorporation in response to the same antigens. A defect in the monocyte IgG receptors has been found in certain patients with the disease, and the current study shows that all patients with defective monocyte $\operatorname{IgG}$ receptors responded to transfer factor, whereas only one patient with normal receptors showed any response. This test may thus prove to be useful in predicting the results of transfer factor therapy in patients with Wiskott-Aldrich syndrome, although evaluation of a larger series of patients will be necessary to confirm this point. We conclude that cellular immunity can be induced, that there appears to be clinical benefit in certain patients with Wiskott-Aldrich syndrome by the use of transfer factor. and that this mode of therapy warrents trial in these patients and others with defects of cellular immunity.

\section{INTRODUCTION}

The Wiskott-Aldrich syndrome $(\mathrm{WAS})^{1}$ is an X-linked disease characterized by recurrent pyogenic infections,

\footnotetext{
1 Abbreviations used in the paper: KLH, keyhole limpet hemocyanin; MIF, migration inhibitory factor; PPD, purified protein derivative; $T$ cells, thymus-dependent lymphocytes; WAS, Wiskott-Aldrich syndrome.
} 
eczema, and thrombocytopenia $(1,2)$. Patients with this syndrome have lymphopenia, lack delayed hypersensitivity as assayed by skin tests, and have lymphocytes which are defective in vitro in response to phytohemagglutinin (PHA) and to specific antigens as measured by radioactive thymidine incorporation into DNA (3). These patients may also have a subnormal antibody response to carbohydrate, but not to protein, antigens (4). Most affected children die in infancy or early childhood $(5,6)$.

Because the disease is almost certainly fatal, heroic methods of therapy have been attempted, but they have not been particularly effective. Administration of immunocompetent cells has a high risk of mortality because of graft vs. host reactions and the consequent need for high doses of immunosuppressive drugs. Lawrence (7) has found that small doses of transfer factor (a nonimmunogenic dialysate of peripheral blood leukocytes) from tuberculin-positive donors will result in positive tuberculin skin tests in recipients who were previously negative. Some investigators believe, but have not proved. that release of transfer factor from transplanted bone marrow, thymus, or whole lymphocytes has resulted in the clinical improvement seen in some patients who were given such transplants as treatment for immunodeficiency diseases. The chemical composition of transfer factor and its mechanism of action are poorly understood.

We have previously treated one patient with WiskottAldrich syndrome with large doses of transfer factor (8). The patient's clinical improvement was striking: he became free of infections, his splenomegaly regressed, his eczema cleared, and new hair began to grow in previous areas of alopecia. Simultaneously, he showed skin reactivity to test antigens, and his lymphocytes acquired the ability to produce migration inhibitory factor (MIF) in response to antigenic stimulation although they remained unable to increase synthesis of DNA in response to the antigen. Other investigators (9) treated a patient with mucocutaneous candidiasis with transfer factor, and reported clinical improvement but the simultaneous administration of amphotericin B make clear interpretation of their results ambiguous. Transfer factor has also been administered, but without clinically apparent benefit, to other patients with mucocutaneous candidiasis $(10,11)$ and to patients with leprosy $(12)$.

The success of therapy with transfer factor in our original patient led to the current study; we present here the clinical and laboratory results of administration of transfer factor to 12 patients with WAS.

\section{METHODS}

Patients. 12 patients with WAS were studied. Seven of the patients were cared for at the University of California, San Francisco Medical Center at Kaiser Hospital, San Francisco, while five patients were hospitalized for evalua- tion and transfer factor therapy elsewhere. D. S. was under the care of Dr. Bernard Pirofsky, Portland, Oreg.; R. R. was under the care of Dr. Charles August, Denver, Colo.; C. T. was under the care of Dr. Richard Stiehm, Los Angeles, Calif.; T. R. was cared for by Richard Gatti, Minneapolis, Minn.; and D. H. was cared for by Dr. Walter Hitzig, Zurich, Switzerland.

Transfer factor. Normal adult blood donors were selected on the basis of skin test reactivity. Only subjects who were strongly reactive to testing with purified protein derivative (PPD) were selected, as this was used as the primary marker antigen. Donors were skin tested with the full panel of test antigens indicated below, and transfer factor preparations from individual donors were not pooled so that the specificity of the transfers could be determined.

All procedures were performed under sterile conditions. $500 \mathrm{ml}$ of blood was drawn into $50-\mathrm{ml}$ syringes containing sodium EDTA and $10 \%$ dextran, ${ }^{2}$ and allowed to sediment for $2 \mathrm{hr}$. The plasma buffy-coat layer was collected and centrifuged for $10 \mathrm{~min}$ at $4^{\circ} \mathrm{C}$. The packed cell volume and total cell count was recorded. The yield of leukocytes from this amount of blood was $2-4 \times 10^{9}$ cells. The cells were resuspended in $4 \mathrm{ml}$ of pyrogen-free saline and alternatively frozen and thawed 10 times, using an acetone-dry ice mixture and a $37^{\circ} \mathrm{C}$ water bath. Magnesium and DNAse ${ }^{3}$ were added, and the mixture was incubated at $37^{\circ} \mathrm{C}$ for $30 \mathrm{~min}$. The resultant cell lysate was dialyzed in washed, ethanolsterilized dialysis tubing ${ }^{4}$ for $24 \mathrm{hr}$ against $500 \mathrm{ml}$ sterile pyrogen-free distilled water in the cold. The distilled water was then changed and the cell lysate redialyzed against a $500 \mathrm{ml}$ sample. The resultant $1000 \mathrm{ml}$ of dialysate (transfer factor) was lyophilized, redissolved in $2 \mathrm{ml}$ of normal saline, passed through a $0.22 \mathrm{~m} \mu$ Millipore filter, and stored at $-20^{\circ} \mathrm{C}$ until use. For use elsewhere, the transfer factor was packed in dry ice and shipped via direct flight as a special service of the airlines. In all cases the transfer factor arrived within $24 \mathrm{hr}$ of shipment and was still frozen on arrival.

Skin tests. All patients were skin tested with a battery of six skin test antigens: candida (Dermatophytin $\mathrm{O}$ ), $1: 100$ and $1: 10 ;^{5}$ coccidiodin, $1: 100$ and $1: 10 ;^{6}$ mumps; $;^{7}$ PPD from tubercle bacillus, intermediate and second strength ${ }^{8}$ streptokinase-streptodornase (Varidase), 4/1 U and 40/10 $\mathrm{U} ;{ }^{\circ}$ and trichophytin (Dermatophytin) $1: 30 .^{5}$

Lymphocyte DNA synthesis. Lymphocyte incorporation of radioactive thymidine in response to antigen was determined by a modification of the method of Kirkpatrick, Stites, Smith, and Johnson (13). $3 \times 10^{8}$ lymphocytes were cultured in triplicate tubes with minimal essential medium containing $10 \%$ fetal calf serum. Appropriate antigens or mitogen were added to experimental tubes at the beginning of culture. The mitogen was phytohemagglutinin $\mathrm{M}^{10}$ at concentrations of 10,100 , and $1000 \mu \mathrm{g} / \mathrm{ml}$. The antigen doses utilized were previously determined to give a maximal response under the conditions of our cultures. This

\footnotetext{
${ }^{2}$ Macrodex 6\%, Pharmacia Laboratories Inc., Piscataway, N. J.

${ }^{3}$ Worthington Biochemical Corp., Freehold, N. J.

- Union Carbide Corp., Chicago, Ill.

${ }^{5}$ Hollister-Stier Laboratories Inc., Spokane, Wash.

- Cutter Laboratories, Berkeley, Calif.

${ }^{7}$ Eli Lilly and Company, Indianapolis, Ind.

${ }^{8}$ Merck, Sharpe, and Dohme Ltd., West Point, Pa.

'Lederle Laboratories Div.. American Cyanamid Co., Pearl River, N. Y.

${ }^{10}$ Difco Laboratories, Detroit, Mich.
} 
included PPD, $15 \mu \mathrm{g} / \mathrm{ml},{ }^{11}$ coccidiodin $1: 10$ dilution, ${ }^{12}$ streptokinase-streptodornase $100 \mu \mathrm{g} / \mathrm{ml},{ }^{8}$ and Dermatophytin $\mathrm{O},{ }^{5}$ 1:50 dilution. Radioactive thymidine, either ${ }^{14} \mathrm{C}(0.2 \mu \mathrm{Ci})$ or ${ }^{3} \mathrm{H}(2 \mu \mathrm{Ci})$, was added $6 \mathrm{hr}$ before harvest. Cultures for determination of stimulation by phytohemagglutinin were harvested after 3 and 6 days of incubation, and cultures for determination of antigen stimulation were harvested after 6 days of incubation. Counts per minute (cpm) were determined in a liquid scintillation counter and the results reported as the ratio of the mean of triplicate experimental tubes, containing antigen or mitogen, to triplicate control tubes. Cultures performed at other hospitals varied in technical details from that described here, but followed this general pattern.

Migration inhibitory factor. MIF as assayed by the technique of Rocklin, Meyers, and David (14). Triplicate culture tubes were set up, each containing $4.5 \times 10^{8}$ purified peripheral blood lymphocytes in $1.5 \mathrm{ml}$ serum-free culture medium. Antigen (PPD, $15 \mu \mathrm{g},{ }^{13}$ or $0.15 \mathrm{ml}$ of a $1: 10$ dilution of Dermatophytin O) was added to experimental tubes cultured in triplicate. Control tubes contained culture medium with cells but no antigen, or antigens without cells. The supernatants were harvested daily for 3 days and replaced by fresh culture medium containing the original antigen. The supernatants were pooled, dialyzed, lyophilized, and reconstituted to one-fifth of the original volume in culture medium containing $10 \%$ guinea pig serum and $5 \%$ calf serum. These preparations were tested for the presence of MIF using guinea pig peritoneal exudates as the indicator cells. Each supernatant was tested with at least two capillary tubes, and whenever the original lymphocyte yield was sufficient, the test was repeated with cells derived from three different guinea pigs. Results are expressed as per cent migration in experimental supernatants (derived from lymphocyte cultures with antigen), compared to migration in control supernatants (derived from lymphocyte cultures without antigen). Previous studies have indicated that significant MIF production has occurred when the migration in experimental chambers is less than $80 \%$ of the migration in control chambers. For patients studied elsewhere, cultures were performed according to the procedure described, and the frozen or lyophilized preparations shipped by direct flight to one of us (L. E. S.) for testing.

Treatment. All patients underwent complete general and immunologic evaluation and were tested with the complete battery of skin test antigens and whenever possible, lymphocyte DNA synthesis and MIF production were measured. (The in vitro evaluation was precluded in some patients because they were too small and/or sick to permit drawing the necessary amount of blood.) After completion of the initial evaluation, $1 \mathrm{U}$ of transfer factor (that amount derived from $1 \times 10^{\circ}$ leukocytes) was injected subcutaneously in two injection sites over the deltoid area or anterior thighs. In some cases the local transfer of reactivity was also measured by injecting $0.1 \mathrm{ml}$ of transfer factor intradermally and skin testing $24 \mathrm{hr}$ later with PPD at the site of injection. 10 days after the systemic transfer, all skin tests were repeated as were the in vitro tests (MIF production and lymphocyte DNA synthesis). The patients were followed by clinical and laboratory evaluation at regular intervals thereafter. Certain patients were given repeated

" Parke, Davis and Company, Detroit, Mich.

12 Supplied by Dr. D. Pappiagianis, University of California, Davis, Calif.

${ }^{13}$ Kindly supplied by the Ministry of Agriculture, Fisheries and Food, Weybridge, England. therapy with transfer factor if they failed to respond clinically, if their skin tests did not show conversion, or if they showed a response and subsequently experienced a relapse.

\section{RESULTS}

The clinical results of transfer factor therapy are shown in Table I. 7 of the 12 patients appeared to respond to transfer factor. Improvement as manifested by relative freedom from infections was noted in 6 of 10 patients who had previously suffered from recurrent severe infections. 3 of the 9 patients with splenomegaly had regression of splenomegaly and 5 of 11 with eczema experienced improvement or disappearance of eczema. An unexpected finding was improvement in the bleeding tendency in 3 of 10 patients.

The results of the laboratory studies before and after transfer factor are shown in Table II and the over-all summary of the clinical and laboratory results are summarized in Table III. 7 of 12 patients showed conversion of skin reactivity; these were the same patients who showed clinical improvement. When tested, the lymphocytes of these patients produced MIF in response to the appropriate antigens, after but not before transfer factor administration, but they did not undergo radioactive thymidine incorporation. The lymphocytes of one patient, C. P., were stimulated by antigen after transfer factor but cultures obtained before transfer factor were not viable.

There was no change in the erythrocyte isohemagglutinin titers after transfer factor therapy. One patient. D. S., was immunized with human A substance, ancl serum studies showed a one to two tube change in the titer of anti-A. There was no consistant change in the white blood count or lymphocyte count. The platelet counts rose slightly in the three patients who showed improvement in bleeding. but this was not a significant change.

In order to determine the specificity of the transfers, both the donors and recipients were tested with six skin test antigens as dscribed. The recipients showed conversion of skin reactivity to some, but not necessarily all, of the antigens to which the donor was sensitive. One patient, J. P., showed conversion of reactivity to an antigen, trichophytin, to which the donor was skin test negative, but this was seen in one test only and occurred very late: 3 months after the administration of transfer factor. In one additional patient, D. S., the skin test to keyhole limpet hemocyanin (KLH) became positive after transfer factor (the patient had previously been immunized to $\mathrm{KLH}$ with negative results); the donor was not tested for sensitivity to $\mathrm{KLH}$.

The results of the study in J. P., are summarized in Table II and illustrated in Fig. 1. The clinical improvement, conversion of skin reactivity, and MIF production after the first dose of transfer factor has been reported previously (8). 6 months after the initial treatment 
TABLE I

Results of Transfer Factor Therapy-Clinical

\begin{tabular}{|c|c|c|c|c|c|c|c|c|}
\hline \multirow[b]{2}{*}{ Pateint } & \multicolumn{2}{|c|}{ Infections } & \multicolumn{2}{|c|}{ Splenomegaly } & \multicolumn{2}{|c|}{ Eczema } & \multicolumn{2}{|c|}{ Bleeding } \\
\hline & Before & After & Before & After & Before & After & Before & After \\
\hline J. P. & Yes & None & Yes & None & Yes & None & No & No \\
\hline R. Z.* & Yes & Yes & Yes & Yes & Yes & Yes & Yes & Yes \\
\hline Kev. C. & Yes & None & Yes & None & Yes & Improved & Yes & \\
\hline K. N. & Yes & Yes & Yes & Yes & Yes & Yes & Mild & Mild \\
\hline I). S. $\ddagger$ & Yes & Improved & Yes & None & Yes & Improved & Yes & Improved \\
\hline R. R. & Yes & Improved & Yes & Yes & No & No & Yes & Improved \\
\hline C. T. & Yes & Yes & Yes & Yes & Yes & Yes & Yes & Yes \\
\hline T. R. $\S$ & No & No & & Yes & Yes & Yes & Yes & Yes \\
\hline D. H. & Yes & No & Yes & Yes & Yes & Yes & Yes & Yes \\
\hline S. G. & No & No\| & No & No & Yes & Improved & Yes & Improved \\
\hline V.S. & Yes & Yes & Yes & Yes & Yes & Improved $\uparrow$ & Yes & Yes \\
\hline C. P. & Yes & Improved & No & No & Yes & Yes & No & No \\
\hline Summary & & $6 / 10^{* *}$ & & $3 / 9$ & & $5 / 11$ & & $3 / 10$ \\
\hline
\end{tabular}

* Died, leukemia, pseudomonas pneumonitis.

$\ddagger$ Died, amphotericin toxicity.

\& Died, cerebral hemorrhage.

\| Mild herpes infection shortly after transfer factor.

I Mild improvement in eczema with no other parameters of improvement noted.

** Number responding/number at risk.

with $\frac{1}{2} U$ of transfer factor, his skin tests and his MIF production became negative. His splenomegaly, eczema, and partial alopecia returned. He developed in succession otitis media, pneumonitis, and meningitis. These infections were treated with appropriate antibiotics and after his recovery, he was again treated with transfer factor. When tested 10 days later, his skin test was negative but his MIF production had become positive. His splenomegaly again regressed, his eczema cleared, and new hair growth began. 6 months later his skin test and MIF again became negative and his symptoms reappeared. $\mathrm{He}$ was retreated with transfer factor before infections developed, and continued to remain free of infections and to participate in all family and school activities, including camping. 6 months later, the return of splenomegaly was noted by the private physician, and the patient also had recurrent eczema and seborrhea. Transfer factor therapy was delayed for a week's camping trip. Shortly after his return, the patient developed a severe Hemophilus influenzae cellulitis of the face, 2 days before the scheduled transfer factor therapy. He was treated with antibiotics followed by transfer factor, with complete recovery. He has now completed four cycles of therapy with similar clinical and laboratory findings with every cycle.

R. R. had a history of bronchiectasis and recurrent pneumonitis. He also had gastrointestinal bleeding with a monthly transfusion requirement. His general supportive care, including weekly infusion of $120 \mathrm{cc}$ of freshly frozen maternal plasma, was improved at the time transfer factor was given, so not all changes can be ascribed to transfer factor. After transfer factor therapy, he remained well, free of infections, and had no further transfusion requirement. The mean platelet count of five determinations before transfer factor was $25,000(12,500$ $42,000)$ and the mean of 9 counts after therapy was $41,400(12,500-72,500) .6$ months after the administration of transfer factor, his skin tests again became negative, he developed an infection, and again required a

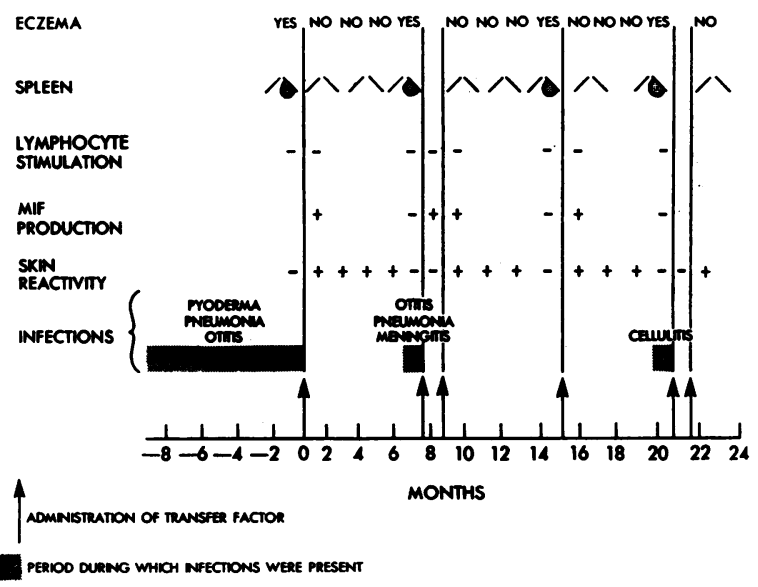

FIGURE 1 Clinical course after transfer factor therapy in a patient with the Wiskott-Aldrich Syndrome. Therapy with transfer was initiated at month 0 . 
Table II

Results of Transfer Factor Therapy-Laboratory

\begin{tabular}{|c|c|c|c|c|c|c|c|c|c|c|c|c|c|c|c|c|}
\hline \multirow[b]{2}{*}{ Patient } & \multirow[b]{2}{*}{$\begin{array}{l}\text { Patient } \\
\text { No. }\end{array}$} & & \multicolumn{6}{|c|}{ Skin reactivity } & \multicolumn{5}{|c|}{ Lymphocyte stimulation } & \multicolumn{3}{|c|}{$\begin{array}{c}\text { Macrophage } \\
\text { migration }\end{array}$} \\
\hline & & & (a) & Co & $\mathbf{M}$ & PPD & SK-SD & $\begin{array}{l}\text { Tricho- } \\
\text { phytin }\end{array}$ & PHA & $\mathrm{Ca}$ & Co & PPD & SK-SD & $\mathrm{Ca}$ & PPD & SK-SD \\
\hline & & & \multicolumn{6}{|c|}{$m m$ induration } & $E / C$ & $E / C$ & $E C$ & $E / C$ & E'r & $y$ & $\%$ & $\%$ \\
\hline $\begin{array}{l}\text { J. } \mathrm{P}_{12 / 1 / 69}^{*}\end{array}$ & 1 & $\begin{array}{l}\mathrm{B} \\
\mathrm{A}\end{array}$ & $\begin{array}{l}0 \\
0\end{array}$ & $\begin{array}{l}0 \\
0\end{array}$ & $\begin{array}{l}0 \\
5\end{array}$ & $\begin{array}{l}0 \\
8\end{array}$ & $\begin{array}{l}0 \\
5\end{array}$ & $\begin{array}{l}0 \\
0\end{array}$ & $\begin{array}{l}8.6 \\
9.0\end{array}$ & & & $\begin{array}{l}1.5 \\
1.1\end{array}$ & & & 0.3 & \\
\hline J. ${ }_{9 / 10 / 70}$ & 2 & $\begin{array}{l}\mathrm{B} \\
\mathrm{A}\end{array}$ & $\begin{array}{l}0 \\
0\end{array}$ & $\begin{array}{l}0 \\
0\end{array}$ & $\begin{array}{l}0 \\
0\end{array}$ & $\begin{array}{l}0 \\
0\end{array}$ & $\begin{array}{l}0 \\
0\end{array}$ & $\begin{array}{l}0 \\
0\end{array}$ & 9.1 & & 1.0 & 1.0 & & & $\begin{array}{r}107 \\
40\end{array}$ & \\
\hline $\begin{array}{l}\text { J. P. } \\
9 / 23 / 70\end{array}$ & 3 & $\begin{array}{l}\mathrm{B} \\
\mathrm{A}\end{array}$ & $\begin{array}{l}0 \\
5\end{array}$ & $\begin{array}{l}0 \\
0\end{array}$ & $\begin{array}{l}0 \\
7\end{array}$ & $\begin{array}{l}0 \\
7\end{array}$ & $\begin{array}{l}0 \\
0\end{array}$ & $\begin{array}{l}0 \\
2\end{array}$ & & & & & & & $\begin{array}{l}40 \\
33\end{array}$ & \\
\hline $\mathrm{J} . \mathrm{P}_{3 / 9 / 71}$ & 4 & $\begin{array}{l}\mathrm{B} \\
\mathrm{A}\end{array}$ & $\begin{array}{l}0 \\
0\end{array}$ & $\begin{array}{l}0 \\
0\end{array}$ & $\begin{array}{l}5 \\
8\end{array}$ & $\begin{array}{l}0 \\
6\end{array}$ & $\begin{array}{l}0 \\
2\end{array}$ & $\begin{array}{l}0 \\
0\end{array}$ & & & & $\begin{array}{l}1.0 \\
1.0\end{array}$ & $\begin{array}{l}1.0 \\
1.0\end{array}$ & & $\begin{array}{l}90 \\
62\end{array}$ & \\
\hline R. Z. & & $\begin{array}{l}\mathrm{B} \\
\mathrm{A}\end{array}$ & $\begin{array}{l}0 \\
0\end{array}$ & $\begin{array}{l}0 \\
0\end{array}$ & $\begin{array}{l}0 \\
0\end{array}$ & $\begin{array}{l}0 \\
0\end{array}$ & $\begin{array}{l}0 \\
0\end{array}$ & $\begin{array}{l}0 \\
0\end{array}$ & 8.8 & & & 1.0 & & & 102 & \\
\hline $\begin{array}{l}\text { Kev. C.* } \\
9 / 24 / 70\end{array}$ & 1 & $\begin{array}{l}\mathrm{B} \\
\mathrm{A}\end{array}$ & $\begin{array}{r}0 \\
10\end{array}$ & $\begin{array}{l}0 \\
3\end{array}$ & $\begin{array}{r}0 \\
12\end{array}$ & $\begin{array}{r}0 \\
10\end{array}$ & $\begin{array}{l}0 \\
3\end{array}$ & $\begin{array}{l}0 \\
0\end{array}$ & $\begin{array}{l}5.2 \\
8.0\end{array}$ & & $\begin{array}{l}1.3 \\
1.0\end{array}$ & $\begin{array}{l}1.0 \\
1.0\end{array}$ & $\begin{array}{l}1.5 \\
1.0\end{array}$ & & $\begin{array}{l}90 \\
81\end{array}$ & \\
\hline $\begin{array}{l}\text { Kev. C. } \\
10 / 5 / 70\end{array}$ & 2 & $\begin{array}{l}B \\
\Lambda\end{array}$ & $\begin{array}{l}10 \\
10\end{array}$ & $\begin{array}{l}3 \\
3\end{array}$ & $\begin{array}{l}12 \\
12\end{array}$ & $\begin{array}{l}10 \\
14\end{array}$ & $\begin{array}{l}3 \\
3\end{array}$ & $\begin{array}{l}0 \\
0\end{array}$ & 8.11 & & 1.0 & 1.0 & 1.0 & & 81 & \\
\hline $\begin{array}{l}\text { K. N. } \\
9 / 3 / 70\end{array}$ & 1 & $\begin{array}{l}\mathrm{B} \\
\mathrm{A}\end{array}$ & $\begin{array}{l}0 \\
0\end{array}$ & $\begin{array}{l}0 \\
0\end{array}$ & $\begin{array}{l}6 \\
6\end{array}$ & $\begin{array}{l}0 \\
0\end{array}$ & $\begin{array}{l}0 \\
0\end{array}$ & $\begin{array}{l}0 \\
0\end{array}$ & $\begin{array}{l}54.1 \\
.38\end{array}$ & & $\begin{array}{l}1.0 \\
1.1\end{array}$ & $\begin{array}{l}1.0 \\
1.2\end{array}$ & $\begin{array}{l}1.1 \\
1.1\end{array}$ & & $\begin{array}{l}17 \\
95\end{array}$ & \\
\hline K. N. & 2 & $\begin{array}{l}B \\
\Lambda\end{array}$ & $\begin{array}{l}4 \\
4\end{array}$ & $\begin{array}{l}0 \\
0\end{array}$ & $\begin{array}{l}5 \\
5\end{array}$ & $\begin{array}{l}0 \\
0\end{array}$ & $\begin{array}{l}0 \\
0\end{array}$ & $\begin{array}{l}0 \\
0\end{array}$ & & & & & & & $\begin{array}{r}95 \\
121\end{array}$ & 126 \\
\hline K. N. & 3 & $\begin{array}{l}\mathrm{B} \\
\mathrm{A}\end{array}$ & $\begin{array}{l}5 \\
5\end{array}$ & $\begin{array}{l}0 \\
0\end{array}$ & $\begin{array}{l}5 \\
5\end{array}$ & $\begin{array}{l}0 \\
0\end{array}$ & $\begin{array}{l}0 \\
0\end{array}$ & $\begin{array}{l}0 \\
0\end{array}$ & & & & & & & 88 & 67 \\
\hline D. S. ${ }^{*}$ & & $\begin{array}{l}\mathrm{B} \\
\mathrm{A}\end{array}$ & $\begin{array}{r}0 \\
22\end{array}$ & $\begin{array}{l}0 \\
0\end{array}$ & $\begin{array}{l}0 \\
8\end{array}$ & $\begin{array}{l}0 \\
0\end{array}$ & $\begin{array}{l}0 \\
0\end{array}$ & $\begin{array}{r}0 \\
13\end{array}$ & 3.3 & & & & & & $\begin{array}{r}141 \\
70\end{array}$ & $\begin{array}{r}139 \\
90\end{array}$ \\
\hline R. R.* & 1 & B & $\begin{array}{l}0 \\
0\end{array}$ & & $\begin{array}{r}0 \\
25\end{array}$ & $\begin{array}{l}0 \\
0\end{array}$ & $\begin{array}{l}0 \\
0\end{array}$ & $\begin{array}{l}0 \\
0\end{array}$ & $\begin{array}{l}30 \\
61\end{array}$ & $\begin{array}{l}4.9 \\
2\end{array}$ & & & 1.4 & & & \\
\hline R. R. & 2 & $\begin{array}{l}\mathrm{B} \\
\mathrm{I}\end{array}$ & () & & 0 & $\begin{array}{r}0 \\
1.3\end{array}$ & 0 & 0 & 32 & 10 & & 0.5 & 0.3 & & & 100 \\
\hline C. T. & 1 & $\begin{array}{l}\mathrm{B} \\
\mathrm{A}\end{array}$ & $\begin{array}{l}0 \\
0\end{array}$ & $\begin{array}{l}0 \\
0\end{array}$ & $\begin{array}{l}0 \\
0\end{array}$ & $\begin{array}{l}0 \\
0\end{array}$ & $\begin{array}{l}0 \\
0\end{array}$ & $\begin{array}{l}0 \\
0\end{array}$ & $\begin{array}{l}\text { Dimini } \\
\text { Dimini }\end{array}$ & ished & & & & & & \\
\hline C. $T_{1 / 21 / 71}$ & 2 & $\begin{array}{l}\mathrm{B} \\
\mathrm{A}\end{array}$ & $\begin{array}{l}0 \\
0\end{array}$ & $\begin{array}{l}0 \\
0\end{array}$ & $\begin{array}{l}0 \\
0\end{array}$ & $\begin{array}{l}0 \\
0\end{array}$ & $\begin{array}{l}0 \\
0\end{array}$ & $\begin{array}{l}0 \\
0\end{array}$ & $\begin{array}{l}\text { Dimini } \\
\text { Dimini }\end{array}$ & $\begin{array}{l}\text { ished } \\
\text { ished }\end{array}$ & & & & & & \\
\hline T. R. & & $\begin{array}{l}\mathrm{B} \\
\mathrm{A}\end{array}$ & $\begin{array}{l}0 \\
0\end{array}$ & $\begin{array}{l}0 \\
0\end{array}$ & $\begin{array}{l}0 \\
0\end{array}$ & $\begin{array}{l}0 \\
0\end{array}$ & $\begin{array}{l}0 \\
0\end{array}$ & $\begin{array}{l}0 \\
0\end{array}$ & & & & & & & & \\
\hline D. ${ }_{6 / 14 / 71}^{H}$ & & $\begin{array}{l}\mathrm{B} \\
\mathrm{A}\end{array}$ & $\begin{array}{c}0 \\
20\end{array}$ & $\begin{array}{l}0 \\
0\end{array}$ & $\begin{array}{l}0 \\
0\end{array}$ & $\begin{array}{l}5 \\
0\end{array}$ & $\begin{array}{l}0 \\
0\end{array}$ & $\begin{array}{l}0 \\
0\end{array}$ & 381 & 1.0 & & & & $\begin{array}{l}73 \\
51\end{array}$ & $\begin{array}{l}64 \\
76\end{array}$ & \\
\hline $\begin{array}{l}\text { S. G.* } \\
9 / 30 / 71\end{array}$ & 1 & $\begin{array}{l}\mathrm{B} \\
\mathrm{A}\end{array}$ & $\begin{array}{l}0 \\
2\end{array}$ & $\begin{array}{l}0 \\
9\end{array}$ & $\begin{array}{l}6 \\
7\end{array}$ & $\begin{array}{r}0 \\
10\end{array}$ & $\begin{array}{l}0 \\
2\end{array}$ & $\begin{array}{l}0 \\
2\end{array}$ & $\begin{array}{l}60.3 \\
31.0\end{array}$ & $\begin{array}{l}1.6 \\
1.2\end{array}$ & $\begin{array}{l}1.5 \\
0.8\end{array}$ & 0.9 & & 75 & $\begin{array}{l}83 \\
46\end{array}$ & 90 \\
\hline $\begin{array}{l}\text { S. G. } \\
11 / 26 / 71\end{array}$ & 2 & $\begin{array}{l}\text { B } \\
\text { A }\end{array}$ & $\begin{array}{l}0 \\
0\end{array}$ & $\begin{array}{r}6 \\
12\end{array}$ & $\begin{array}{l}0 \\
2\end{array}$ & $\begin{array}{l}0 \\
0\end{array}$ & $\begin{array}{l}0 \\
5\end{array}$ & $\begin{array}{l}0 \\
5\end{array}$ & & & & & & & & \\
\hline V.S. & 1 & $\begin{array}{l}\mathrm{B} \\
\mathrm{A}\end{array}$ & 0 & 0 & 5 & 2 & 2 & 2 & 3.6 & 1.3 & & 1.3 & & $\begin{array}{r}112 \\
75\end{array}$ & $\begin{array}{r}141 \\
84\end{array}$ & 1.0 \\
\hline C. $P_{11 / 8 / 72}^{*}$ & 1 & $\begin{array}{l}\text { B } \\
\text { A }\end{array}$ & 0 & 0 & 13 & 0 & 0 & 0 & & & & & & 113 & 98 & \\
\hline C. $P_{1 / 31 / 72}$ & 2 & $\begin{array}{l}\text { B } \\
\text { A }\end{array}$ & & & & & & & & & & & & & & \\
\hline Summary & & & & & $7 / 12 \|$ & & & & $0 / 5$ & & & $0 / 6$ & & & & $6 / 8$ \\
\hline
\end{tabular}

B, before administration of transfer factor.

A, after administration of transfer factor.

* Responded to transfer factor.

$\ddagger E / C$ : counts per minute in experimental tubes with antigen/counts per minute in control tubes without antigen.

$\$$ Per cent migration in supernatants from experimental culture with antigen compared to migration in supernatants from control cultures without antigen. Less than $80 \%$ migration indicated production of MIF.

II Number showing conversion of parameter/number tested. 
TABLE III

Results of Transfer Factor Therapy in the Wiskott-Aldrich Syndrome

\begin{tabular}{|c|c|c|c|c|c|c|c|}
\hline Patient & $\begin{array}{l}\text { Improvement } \\
\text { in } \\
\text { infections }\end{array}$ & $\begin{array}{c}\text { Conversion } \\
\text { of } \\
\text { skin reactivity }\end{array}$ & $\begin{array}{l}\text { Regression } \\
\text { or } \\
\text { splenomegaly }\end{array}$ & $\begin{array}{c}\text { Clearing } \\
\text { of } \\
\text { eczema }\end{array}$ & $\begin{array}{l}\text { Lymphocyte } \\
\text { stimulation }\end{array}$ & $\begin{array}{c}\text { MIF } \\
\text { production }\end{array}$ & $\begin{array}{l}\text { Monocyte } \\
\text { IgG receptor }\end{array}$ \\
\hline 1. J. P. & Yes & Yes & Yes & Yes & No & Yes & A \\
\hline 2. R. Z.* & No & No & No & No & No & No & \\
\hline 3. K. C. & Yes & Yes & Yes & Yes & No & Yes & $A$ \\
\hline 4. K. N. & No & No & No & No & No & No & \\
\hline 5. D. S. (Pirofsky) $\ddagger$ & Yes & Yes & Yes & Yes & No & Yes & \\
\hline 6. R. R. (August) & Yes & Yes & No & - & No & & A \\
\hline 7. C. T. (Stiehm) & No & No & No & No & No & & $\mathrm{N}$ \\
\hline 8. T. R. (Gatti)§ & None present & No & - & No & & & \\
\hline 9. D. H. (Hitzig) & Yes & Yes & - & No & No & Yes & A \\
\hline 10. S. G. & None present & Yes & None present & Yes & No & Yes & $\mathrm{N}$ \\
\hline 11. V.S. & No & No & No & Partial & No & No & $\mathrm{N}$ \\
\hline 12. C. P. & Yes & Yes & None present & No & Yes & Yes & \\
\hline Summary & $6 / 10 \|$ & $7 / 12$ & & $5 / 11$ & $1 / 9$ & $6 / 9$ & $4 / 8$ \\
\hline
\end{tabular}

A, abnormal (diminished number of monocytes having IgG receptors); $\mathrm{N}$, normal.

* Died, leukemia, pseudomonas pneumonitis.

$\ddagger$ Died, amphotericin toxicity.

$\$$ Died, cerebral hemorrhage.

|| Number responding/number at risk.

blood transfusion. After a second treatment with transfer factor, he again improved. The timing of these changes was similar to those noted for J. P.

K. N. was clinically similar to the other patients. He clearly had WAS, and there was a strong family history of 11 members who died of WAS, two of which were documented at this hospital. He was clinically uninfected at the time of therapy, but did not respond to transfer factor even though it was given on four occasions.

C. T. was clinically ill at the time of the administration of the first dose of transfer factor. He did not show improvement clinically nor did his skin test reactivity become positive. After several months, he was given transfer factor again, with similar negative results.

V. S. a 12-yr old boy, was found to have a mediastinal mass at the time he was admitted for evaluation. Bone marrow examination and lymph node biopsy did not establish the diagnosis, although it is strongly suspected that the mass represents lymphoma. He was treated with 2 doses of transfer factor, and did not show any response except for some improvement in his eczema. He continued to experience infections, and there was no change in his skin reactivity and no MIF production.

S. G. entered the hospital with a white cell count of 8,000 and platelet count of 30,000 . He had a large bruise over his hip which had resulted from mild trauma. 1 wk after the administration of transfer factor, he became febrile and developed a herpes lesion on his lip. His white count fell to 2,400 and his platelets to 9,000 . The illness continued for about a week, after which he be- came afebrile, his herpes cleared, his white cell count rose to 8,000 and his platelets rose to 110,000 . His eczema cleared completely and his skin tests became positive. When he jumped from a bed, sustaining a severe bump to his knee, he did not experience bruising or bleeding. His platelet count subsequently decreased, and his eczema returned; these were unchanged by another dose of transfer factor, although his skin tests became more strongly positive.

Five of the patients had infections which were not prevented by the administration of transfer factor. Except for S. G. those were all patients who showed no response to transfer factor therapy. R. $Z$. had severe pseudomonas pneumonitis at the time he was treated and died 10 days later. $\mathrm{K}$. N. has been treated with transfer factor on several occasions without reducing the infection rate. C. T. had an infection at the time of therapy, and it continued unchanged after therapy. V. S. developed chills and fever after therapy, and was found to have a staphylococcal bacteremia. S. G. became febrile a week after therapy, and was found to have an herpes infection.

Three of the patients have died. R. Z. was terminally ill with pseudomonas pneumonitis and probable leukemia when treated, and died 10 days after therapy without showing any response to transfer factor. T. R. had a platelet count of 4,000 at the time of treatment. $\mathrm{He}$ was treated with Vincristine and platelet transfusions at the same time as the transfer factor, in an attempt to raise the platelets (15). The platelet count did rise to 43,000 , but nonetheless, he died 9 days after treatment of 
a cerebral hemorrhage without showing conversion of skin reactivity or clinical benefit. D. S., had marked lymphadenopathy and splenomegaly which regressed dramatically after transfer factor. He also had petechiae which cleared shortly after transfer factor was given. His platelet count was 14,000 before therapy and rose gradually to 35,000 concomitant with the regression of splenomegaly after therapy. 2 months after the administration of transfer factor, he developed streptococcal septicemia. It is noteworthy that his skin reaction to streptococcal antigens did not convert after transfer factor. His skin reaction to candida antigen, which had become positive after transfer factor, was found to be negative after his recovery from streptococcal septicemia. Soon thereafter, he developed a candida pneumonitis and died due to amphotericin toxicity.

A defect in the monocyte IgG receptor has been noted in some patients with WAS. ${ }^{14}$ The correlation of this defect with the response to transfer factor therapy is shown in Table III. Four patients had diminished numbers of monocyte $\mathrm{IgG}$ receptors, and these patients all responded to transfer factor. Four other patients, clinically indistinguishable from the others, had normal receptors and only one of these responded to the administration of transfer factor. Statistical analysis indicated a $P$ value of 0.07 as determined by the Fisher's exact test which is applicable to small numbers (16). The defect in the monocyte IgG receptor was not corrected hy the administration of transfer factor, since it was present in four patients after the administration of transfer factor despite a response to transfer factor as determined by other immunologic perameters in these patients.

\section{DISCUSSION}

The response to transfer factor observed in patients with WAS has been encouraging. These patients often undergo periods of relative clinical improvement, and it is often difficult to determine whether such a change may be due to the therapy or to chance "spontaneous" remission. In the case of J. P., however, it seems clear that the changes were due to the transfer factor, as he has been through four identical cycles of remission associated with transfer factor, followed by relapse 6 months later.

The course in R. R., suggested a similar picture. While we cannot rule out spontaneous remission in the other patients, the changes observed did, at least, fol-

\footnotetext{
${ }^{14}$ Spitler, L. E., A. S. Levin, H. H. Fudenberg, and H. Huber. Unpublished observations.
}

low the administration of transfer factor; a longer period of observation will undoubtedly clarify this point. In D. S., septicemia developed with an organism to which cellular immunity had not been established. In addition, candida infection developed shortly after negative conversion of the induced skin reactivity to that antigen. Over 30 patients with WAS have now been treated with transfer factor supplied by our laboratory, and a favorable response has been noted in about one-half of these patients.

The administration of transfer factor caused conversion of skin reactivity in 7 of 12 patients, and in those patients tested, there was also production of MIF, although (except for the response in C. P.) there was no increase DNA synthesis in the lymphocytes. We have previously reported a dissociation between MIF production and DNA synthesis in cells from guinea pigs immunized with the tobacco mosaic virus protein (17). Others subsequently showed a similar dissociation using tuberculin polysaccharide (18). These results suggest that there may be two populations of lymphocytes responsible for these functions; one which undergoes division in response to antigen and another which produces MIF. These responses are both thought to be mediated by the thymus-dependent lymphocytes or " $\mathrm{T}$ " cells, and these would represent two populations of $\mathrm{T}$ cells. The alternative explanation is that this represents two different responses of the same population of lymphocytes.

The unexpected observation of improvement in bleeding in three patients is intriguing. It could perhaps have been due simply to a reduction of spleen size and hypersplenism due to clearing of infections. However, the changes in the platelet count observed seem insufficient to account for the clinical improvement in bleeding. The nature of the platelet defect in WAS has not been clearly defined. The observations that autologous platelets have a shortened survival time in these patients (19) suggests an intrinsic defect in the platelets. It was subsequently demonstrated that platelets of at least some of the patients and carriers of the disease have a metabolic defect in aerobic glycolysis, leading to the suggestion that the metabolic defect could be the basic defect leading to both the platelet and the immunologic abnormalities (20). If this is the case, it is possible that transfer factor could act in some fashion to correct the platelet abnormality as well as the cellular abnormality.

We were interested to see whether the transfer factor therapy would cause an increase in the erythrocyte isohemagglutinin titers of our patients. We postulated that the transfer factor might be acting on the $\mathrm{T}$ cells. There- 
fore, we questioned whether or not the function of the $\mathrm{T}$ cells in promoting antibody formation by the B cells, might be reconstituted, therefore causing a rise in the isohemagglutinins. No such rise was observed, even after immunization in D. S.

The studies regarding the specificity of transfer factor do not definitely answer the question, but support the concept that transfer factor confers specific reactivity. It is not surprising that the recipients did not show reactivity to every antigen to which the donor showed reactvity, since the success of transfer correlates with the strength of the reactivity in the donor. Only on two occasions did the recipient show reactivity to an antigen to which the donor was not known to be sensitive. One of these antigens was $\mathrm{KLH}$, and the donor was not tested for reactivity to this antigen. Since reactivity does occur in some normal subjects, it is possible that the donor did have reactivity to $\mathrm{KLH}$.

The response to transfer factor generally was correlated with the defect in the monocyte IgG receptors. We postulate that in patients with defective monocyte IgG receptors, it is possible to bypass the defect by the use of transfer to reconstitute cellular immunity. In the patients whose monocyte IgG receptors were normal, transfer factor generally did not reconstitute cellular immunity, suggesting that the defect was in a different location, perhaps with the lymphocyte itself. We have thus defined two forms of WAS, one with a defect in the monocyte IgG receptors and good response to transfer factor. Evaluation of a larger series of patients is necessary to confirm this.

We have not observed any adverse reaction to transfer factor therapy. There has been no anaphylaxis, no febrile response, and no evidence of sensitization, even after repeated injections. In contrast, bone marrow transplantation frequently results in death from graft vs. host reaction, and is often used in combination with immunosuppressive agents which may result in overwhelming infection. Based on the results of this study we believe that the use of transfer factor should be explored in this and in other diseases associated with depression of cellular immunity.

\section{ACKNOWLEDGMENTS}

The valuable technical assistance of Mrs. Christine von Muller, Miss Mae Hsu, Miss Janice Perlman, and Miss Lotti Kuhn is gratefully acknowledged. We thank Dr. Robert Good for permitting us to study his patients, S. G. and T. R.

This research was supported by grants from the American Cancer Society (459), the Damon Runyon Cancer So- ciety (DRG-1068), and the American Cancer Society (ET$13 \mathrm{E}$ ), and the USPHS (A1 08677, A1 09145, A1 CA 10686, A1 00798, and HD 05894). Some of the patients were hospitalized in the Pediatric Clinical Research Center, University of California Medical Center, with funds provided by the Division of Research Resources Under PHS-RR79. Studies on R. R. were supported by a grant (R R-69) from the General Clinical Research Centers Program of the Division of Research Resources, NIH and by a grant (IN-5L3) from the American Cancer Society.

\section{REFERENCES}

1. Wiskott, A. 1937. Familiarer angeborener morbus werlhofii. Monatssch. Kinderheilkd. 68: 212.

2. Aldrich, R. A., A. G. Steinberg, and D. C. Campbell. 1954. Pedigree demonstrating a sex-linked recessive condition characterized by draining ears, eczematoid dermatitis and bloody diarrhea. Pediatrics. 13: 133.

3. Oppenheim, J. J., R. M. Blaese, and T. A. Waldman. 1970. Defective lymphocyte transformation and delayed hypersensitivity in Wiskott-Aldrich syndrome. J. Immunol. $104: 835$.

4. Cooper, M. D., H. P. Chase, J. T. Lawman, W. Krivit, and R. A. Good. 1968. Wiskott-Aldrich syndrome. An immunologic deficiency disease involving the afferent limb of immunity. Am. J. Med. 44 : 499.

5. Wolff, J. A. 1967. Wiskott-Aldrich syndrome: clinical, immunologic, and pathologic observations. J. Pediatr. $70: 221$.

6. Mandl, M. A. J., J. I. Watson, and B. Rose. 1968. The Wiskott-Aldrich Syndrome. Immunopathologic mechanisms and a long-term survival. Ann. Intern. Med. 68: 1050.

7. Lawrence, H. S. 1955. The transfer in humans of delayed skin sensitivity to streptococcal $M$ substance and to tuberculin with disrupted leukocytes. J. Clin. Invest. $34: 219$.

8. Levin, A. S., L. E. Spitler, D. P. Stites, and H. H. Fudenberg. 1970. Wiskott-Aldrich syndrome, a genetically determined cellular immunologic deficiency : clinical and laboratory responses to therapy with transfer factor. Proc. Natl. Acad. Sci. U. S. A. 67: 821.

9. Schulkind, M. L., W. H. Adler III, W. A. Altemeier III, and E. M. Ayoub. 1972. Transfer factor in the treatment of a case of chronic mucocutaneous candidiasis. Cell. Immunol. 3 : 606.

10. Rocklin, R. E., R. A. Chilgren, R. Hong, and J. R. David. 1970. Transfer of cellular hypersensitivity in chronic mucocutaneous candidiasis monitored in vivo and in vitro. Cell. Immunol. 1: 290.

11. Kirkpatrick, C. H., R. R. Rich, and J. E. Bennett. 1971. Chronic mucocutaneous candidiasis: model building in cellular immunity. Ann. Intern. Med. 74: 955.

12. Bullock, W. E., J. P. Fields, and M. W. Brandriss. 1972. An evaluation of transfer factor as immunotherapy for patients with lepromatous leprosy. N. Engl. J. Med. In press.

13. Kirkpatrick, C. H., D. P. Stites, T. K. Smith, and R. A. Johnson. 1971. A factor which enhances DNA synthesis in cultures of stimulated lymphocytes. In Proceedings of the Fourth Annual Leukocyte Culture Conference. O. R. McIntyre, editor. Appleton-Century-Croft, New York. 219.

14. Rocklin, R. E., O. L. Meyers, and J. R. David, 1970. 
An in vitro assay for cellular hypersensitivity in man. J. Immunol. 104: 95.

15. Marmont, A. M., E. E. Damasio, and E. Gori. 1971. Vinblastine sulfate in idiopathic thrombocytopenic purpura. Lancet. 11 : 94.

16. Palumbo, D. J. 1969. Statistics in Political and Behavioral Science. Appleton-Century-Croft, New York. 156.

17. Spitler, L. E., E. Benjamini, J. D. Young, H. Kaplan, and H. H. Fudenberg. 1970. Studies on the immune response to a characterized antigenic determinant of the tohacco mosaic virus protein. J. Exp. Med. 131: 133.
18. Chaparas, S. D., D. E. Thor, H. P. Godfrey, H. Bear, and S. R. Hedrick. 1970. Tuberculin-active carbohydrate that induces inhibition of macrophage migration but not lymphocyte transformation. Science (Wash. D. C.). 170: 637.

19. Grottum, K. A., T. Hovig, H. Holsem, A. Foss Abrahamsen, M. Jeremic, and M. Seip. 1969. Wiskott-Aldrich Syndrome: qualitative platelet defects and short platelet survival. Br. J. Haematol. $17: 373$.

20. Kuramoto, A., M. Steiner, and M. G. Baldini. 1970. Lack of platelet response to stimulation in the WiskottAldrich syndrome. N. Engl. I. Mcd. 282: 475. 